\title{
Holding the Sovereign's Universities Accountable for Patent Infringement after Florida Prepaid and College Savings Bank
}

\author{
Jennifer Polse $\dagger$
}

Two terms ago, the Rehnquist Court's expanding doctrine of state sovereign immunity finally engulfed federal intellectual property law. After the Court's decision in Florida Prepaid, states and their universities enjoy broad immunity from suit for violations of the patent law. This ruling comes at a time when state universities, guided by the incentive structure created by the Bayh-Dohl Act, have become increasingly large actors in the patent arena. While Congress must act to curb potential state university abuses of the patent system, it should do so without disrupting the role that federally-funded university research plays in the production of useful inventions. This Comment suggests that Congress should condition receipt of a federal research grant on waiver of sovereign immunity from violations of patent law stemming from the funded research. Such an approach ensures that federal funds cannot be used to violate federal patent law. Moreover, it preserves the Bayh-Dohl Act's incentive structure, which helps guarantee that the fruits of federally-funded research reach the public that paid for them.

In 1982 three researchers at the University of California San Francisco patented their newly invented inethod for producing human growth hormone ("hGH") using recombinant DNA technology. ${ }^{1}$ The University

\footnotetext{
Copyright $\odot 2001$ Califomia Law Review, Inc. California Law Review, Inc. (CLR) is a California nonprofit corporation. CLR and the authors are solely responsible for the content of their publications.

$\uparrow \quad$ J.D. Candidate 2001, School of Law, University of California, Berkeley (Boalt Hall); Ph.D., University of California, Berkeley (Chemistry), 1996, B.A., Wellesley College, 1992. I wish to thank Professors Peter Menell and Robert Merges for their advice and guidance on this Comment. 1 am grateful to Jennifer Urban, Ethan Andelman, and Jason Schultz for many illuminating discussions of this area of law. I also wish thank the members of the California Law Review, especially Kate Barry and Elizabeth Kristen, for their careful editing of this manuscript.

1. Genentech, Inc. v. Eli Lilly \& Co., 998 F.2d 931, 935 (Fed. Cir. 1993) [hereinafter Genentech I. Human growth hormone, normally released by the pituitary gland, stimulates generalized growth.
} 
granted Eli Lilly an exclusive license to practice the patent, thus allegedly locking Genentech, a Lilly competitor, out of the hGH market. ${ }^{2}$ The University then informed Genentech that its production of $h \mathrm{hH}$ infringed the University's patent. Invoking a common patent litigation strategy, Genentech filed suit in federal court in Indiana against the University and Lilly seeking a declaratory judgment that the University's patent was invalid and not infringed. ${ }^{3}$ The Umiversity struck back the following day, filing a patent infringement suit against Genentech in its preferred forum, the Northern District of Califorma. ${ }^{4}$ Genentech's defense claimed invalidity and non-infringement, the same claims it brought im its original declaratory judginent action. Meanwhile, the University counterclaimed for patent infringement in the Indiana suit. ${ }^{5}$

In the end, the two lawsuits ${ }^{6}$ mirrored each other in all respects but one: the Indiana case involved a suit by a private citizen against the Umiversity of Califorma, an arm of the state of Califorma. ${ }^{7}$ The subsequent history of the Genentech case illustrates a troubling loophole in the patent law created by the Supreme Court's ever-expanding doctrine of sovereign immunity: state research universities, increasingly large actors in the patent arena, possess the power to dictate when, where, and how to enforce their federal patent rights and the patent rights of others.

Invoking the doctrine of sovereign immunity, the University moved to dismiss Genentech's declaratory judginent action as barred by both its subsequent infringement action and by the Eleventh Amendment. ${ }^{8}$ The district court granted the University's inotion, holdmg that the Eleventh Amendment ${ }^{9}$ barred it from hearing a patent infringement action against a

Too much hGH in a growing child can result in gigantism, a disease in which the victim never stops growing. In contrast, an hGH deficiency causes dwarfism, a condition in which the child never grows to a normal size. One use for hGH, therefore, is in the treatment of children suffering from dwarfism. Prior to the discovery of a recombinant method for making hGH, the hormone could only be isolated from the pituitary glands of cadavers. The hormone was therefore both rare and costly. The discovery of recombinant DNA technology allowed hGH to be harvested in large quantities from bacteria that had been genetically modified to produce hGH, and the drug is now readily available. DONALD VOET \& JUDITH G. VOET, BIOCHEMISTRY 1150-51 (1990).

2. Genentech 1,998 F.2d at 945 .

3. Id. at 935 .

4. Id.

5. Genentech, Inc. v. Regents of the Umiv. of Cal., 143 F.3d 1446, 1449 (Fed. Cir. 1998) [hereinafter Genentech II], vacated by 527 U.S. 1031 (1999).

6. A total of six lawsuits involving Lilly, Genentech, and the Regents sprang from this set of facts. The actions were consolidated in Indiana for discovery. For a summary of the various suits, see In re Regents of the University of California, 964 F.2d 1128 (Fed. Cir. 1992).

7. Genentech II, 143 F.3d at 1449 n.3.

8. Genentech I, 998 F.2d at 939.

9. U.S. CoNST. amend. XI. The Amendment provides that " $[\mathrm{t}]$ he Judicial power of the United States shall not be construed to extend to any suit in law or equity, commenced or prosecuted against one of the Umited States by Citizens of another State, or by Citizens or Subjects of any Foreign State." Id. 
state. $^{10}$ The Federal Circuit reversed, finding that Congress validly abrogated the states' Eleventh Amendinent immunity from suits arising under the patent law when it passed the Patent and Plant Variety Remedy Clarification Act (the "Patent Remedy Act")" in 1992.12 While the case progressed, the Supreme Court decided in Seminole Tribe of Florida $v$. Florida ${ }^{13}$ that Congress could not abrogate Eleventh Amendinent immunity when it legislated pursuant to its Article I powers. ${ }^{14}$ The district court again dismissed Genentech's suit on Eleventh Amendment grounds, this time holding that because the Patent Remedy Act was passed pursuant to Congress's Article I porvers, it could not abrogate the University's sovereign immunity. ${ }^{15}$ Tenaciously maintaining its jurisdiction over the patent law, the Federal Circuit again reversed, holding that the University constructively waived its immunity by voluntarily accunulating federal patent rights enforceable ouly in federal court and by threatening to invoke the federal judicial powver to enforce those rights. ${ }^{16}$ In a final coup de grace, the Supreme Court reversed and remanded the case for reconsideration ${ }^{17}$ in light of its recent holding in College Savings Bank v. Florida Prepaid Postsecondary Education Expense Board ${ }^{18}$ that states cannot constructively waive Eleventh Amendment immunity from suit in federal court. ${ }^{19}$

After College Savings Bank and its companion case, Florida Prepaid $I I,{ }^{20}$ states enjoy broad immunity from suit for violations of the patent law.

10. Genentech II, 143 F.3d at 1449. The district court also rested its dismissal on its discretion to dismiss an earlier-filed declaratory judgment action in favor of a later-filed infringement suit. Id.

11. 35 U.S.C. $\$ \S 271(\mathrm{~h}), 296$ (a) (1992). Congress passed the Patent Remedy Act in response to the Supreme Court's decision in Atascadero State Hospital v. Scanlon, 473 U.S. 234 (1985). Atascadero held that to abrogate immunity Congress must "mak[e] its intention unmistakably clear in the language of the statute." Id. at 242. The Patent Reinedy Act amended the Patent Act to read that "[a]ny State, and any such instrumentahity, officer, or employee, shall be subject to the provisions of this title in the same manner and to the same extent as any nongovernmental entity." 35 U.S.C. $\S$ 271(h). It further stated that a state "shall not be immune, under the eleventh amendment . . . or under any other doctrine of sovereign immunity, from suit in Federal court by any person . . . for infringement of a patent...."Id. § 296(a).

12. Genentech I, 998 F.2d at 943. The court further held that a first-filed action seeking a declaration of patent rights should not be dismissed simply because the patentee later files an infringement suit. A rule granting such an automatic forum choice to the patentee would be "contrary to the purpose of the Declaratory Judgment Act" because it would not allow "a person caught in controversy to obtain resolution of the dispute, instead of being forced to await the imitiative of the antagonist." Id. at 937.

13. 517 U.S. 44 (1996).

14. Id. at 72 .

15. Genentech II, 143 F.3d at 1449.

16. Id. at 1454.

17. Regents of Univ. of Cal. v. Genentech, Inc., 527 U.S. 1031 (1999).

18. 527 U.S. 666 (1999).

19. Id. at 680 . In the case decided along with College Savings Bank, the Court also held that the Patent Remedy Act exceeded Congress's power and did not validly abrogate Eleventh Amendment immunity from suits under the patent law. Fla. Prepaid Postsecondary Educ. Expense Bd. v. Coll. Savings Bank, 527 U.S. 627 (1999) [hereinafter Florida Prepaid II].

20. 527 U.S. 627 . 
This immunity comes during an era in which universities-both public and private-are rapidly expanding their pursuit of intellectual property by vigorously accumulating and enforcing their federal patent rights. ${ }^{21}$ Indeed, the federal government has deliberately encouraged researchers to patent mventions developed with federal funds, ${ }^{22}$ in part because it beheved that obtaining a patent would increase the likelihood that an invention would be developed and made available to the public. ${ }^{23}$ The Bayh-Dohl Act, ${ }^{24}$ for example, prods universities to produce patentable inventions by allowing federally funded researchers to retain title to their inventions. ${ }^{25}$ The Act succeeded in its goals; following its passage universities greatly increased the rate at which they patented their inventions and hicensed those patents to private industries. ${ }^{26}$ The Court's decision in Florida Prepaid II, however, may turn the Bayh-Dohl Act's success mto failure as the federal government and private industry react to the specter of aggressive state university patentees who cannot be held accountable for damages under the patent law. ${ }^{27}$

Congressional response to the threat of aggressive state infringers and patentees should be sensitive to the special role state universities play in the development of useful new technologies. Congress should act to close the loophole created by Florida Prepaid II and protect the integrity of the patent system. However, Congress's approach should be designed to minimize harm to state university research programs, many of which have produced beneficial inventions. ${ }^{28}$ Although Florida Prepaid II left Congress powerless to directly subject states to suit for patent infringement

21. See generally Kenneth Sutherlin Dueker, Biobusiness on Campus: Commercialization of University-Developed Biomedical Technologies, 52 FooD \& DRUG L.J. 453 (1997); Rebecca S. Eisenberg, Public Research and Private Development: Patents and Technology Transfer in Government-Sponsored Research, 82 VA. L. REv. 1663 (1996). Cf. Sberyl Gay Stolberg, Biomedicine is Receiving New Scrutiny as Scientists Become Entrepreneurs, N.Y. TIMES, Feb. 20, 2000, at A-9 (describing growing number of academic researchers who start spin-off companies to develop their patented inventions). Private universities, of course, also receive federal funding and also create patented inventions. However, unlike their state-owned connterparts, private universities remain fully accountable for violations of federal intellectual property law.

22. Eisenberg, supra note 21 , at 1666 (commenting that "[t]oday, we have in place a system that pervasively promotes patenting federally-sponsored inventions wherever they are made, whether in govemment, university, or private laboratories").

23. Id. at $1698-99$.

24. Pub. L. No. 96-517, $\S 6($ a), 94 Stat. 3015, 3019-27 (codified as amended at 35 U.S.C. $\S \S 200$ 211 (1988)).

25. Id.

26. Eisenberg, supra note 21, at 1708-09.

27. Indeed, a bill introduced in Congress would deny a state the right to receive a patent unless it waives immunity from suit in federal court for violation of any federal intellectual property right for the duration of the patent's term. S. 1835, 106th Cong. $\$ 131$ (c) (1999).

28. For example, the University of California and Stanford University jointly own the CohenBoyer patents on basic recombinant DNA techniques, fundamental building blocks in the biotechnology industry. Eisenberg, supra note 21 , at 1710 . 
in federal court, ${ }^{29}$ the Court may still allow Congress to condition receipt of federal funding on waiver of sovereign immunity. ${ }^{30}$ This Comment argues that the proper balance between maintaining the integrity of the patent system and promoting state universities to patent their research can be reached through the use of the spending power. Specifically, it contends that a state university's receipt of federal research funding should be conditioned on waiver of sovereign immunity from patent suits involving the funded research. Part I reviews the Court's Eleventh Amendinent jurisprudence, focusing particularly on Congress's ability, or lack thereof, to regulate state university patent infringeinent after Seminole Tribe and Florida Prepaid II. Part II describes the role state universities play in the production of useful inventions. That part examines the use of patent incentives to guide university researchers toward the creation of useful inventions, focusing in particular on the Bayh-Dohl Act. Removal of patent incentives might damage the role universities play in the creation of new inventions, while retaining patent incentives for institutions that cannot be sued for infringement might disrupt the patent law in general. Part III suggests that Congress condition provision of federal research funding to state universities on waiver of sovereign immunity froin suits involving patent rights arising from or infringed by the federally funded research.

\section{I}

EleVENTH AMENDMENT IMMUNity FROM SUIT FOR PATENT INFRINGEMENT AFTER SEMINOLE TRIBE, FLORIDA PREPAID AND COLLEGE SAVINGS BANK

Long one of the backwaters of constitutional law, ${ }^{31}$ the Eleventh Amendınent now enjoys a prominent position in the Rehnquist Court's defense of states' rights. The Amendinent provides that '[t]he Judicial power of the United States shall not be construed to extend to any suit in law or equity, commenced or prosecuted against one of the United States by Citizens of another State, or by Citizens or Subjects of any Foreign State." ${ }^{.32}$ Although by its plain text the Amendinent withholds jurisdiction

29. Florida Prepaid II, 527 U.S. 627, 645-46 (1999). But see Coll. Savings Bank v. Fla. Prepaid Postsecondary Educ. Expense Bd, 527 U.S. 666, 702-04 (1999) (Breyer, J., dissenting) (noting that Ex Parte Young, 209 U.S. 123 (1908), may allow Congress to draft legislation allowing suits against states for prospective injunctive relief, and further suggesting that Congress could authorize federal agencies to sue infringers for damages on the patentee's behaif).

30. See Atascadero State Hosp. v. Scanlon, 473 U.S. 234, 238 n.l (1985) (noting, albeit in dicta, that "[a] State may effectuate a waiver of its constitutional immunity ... by otherwise waiving its immunity to suit in the context of a particular federal program"); see also Daniel J. Meitzer, The Seminole Decision and State Sovereign Immunity, 1996 SUP. CT. REv. 1, 50-55 (1996) (noting, but ultimately disapproving of, conditioning waiver of sovereign immunity on provision of federal funds).

31. Meltzer, supra note 30, at 1-2 (noting the infrequency with which Eleventh Amendment issues arose prior to the advent of the Rehnquist Court's resucitation of the issue).

32. U.S. ConsT. amend. XI. 
only when the plaintiff is not a citizen of the defendant state, the Court has extended its reach much further, holding that federal courts cannot hear suits against unconsenting states regardless of the plaintiff's citizenship. ${ }^{33}$

Despite the broad reach of the Eleventh Amendinent, federal courts can still hear suits by citizens against a state if Congress legislatively abrogates the state's sovereign immunity or if the state waives its Eleventh Amendment rights. However, the Rehnquist Court has severely restricted Congress's ability to abrogate Eleventh Amendinent immunity, hobbling the federal government's efforts to enforce federal law against the states. This Part will describe the evolution of the Court's approach to abrogation and waiver of Eleventh Amendinent immunity. It will culminate with a discussion of the Court's recent decisions in Florida Prepaid II and College Savings Bank, both of which severely curtailed the ability to sue a state for violations of federal intellectual property law.

\section{A. Sovereign Immunity Under the Eleventh Amendment}

The Eleventh Amendinent was adopted in response to the Supreme Court's decision in Chisholm v. Georgia. ${ }^{34}$ Chisholm, a citizen of South Carolina, brought suit in federal court against the state of Georgia to collect money it owed him on a contract. ${ }^{35}$ Georgia contested jurisdiction, arguing that sovereign immunity barred an action by a private citizen against an unconsenting state. ${ }^{36}$ Alone ainong the Justices, Justice Iridell argued that the Constitution did not intend to disturb the common law conception of sovereign immunity, which did not permit a private citizen to sue the sovereign without consent. ${ }^{37}$ The other Justices hewed closer to the text of Article III, noting that " $[\mathrm{t}]$ he judicial power ... is expressly extended to 'controversies between a State and citizens of another State."'38 The Court therefore held that Article III provided for jurisdiction over Chisholm's suit. $^{39}$

The Chisholm decision created such a "shock of surprise throughout the country" that at its next session Congress proposed the Eleventh Amendinent, whieh was designed to overrule Chisholm. ${ }^{40}$ Although by its

33. Hans v. Louisiana, 134 U.S. 1, 21 (1890) (holding that the Eleventh Amendment bars citizens from suing their states in federal court).

34. 2 U.S. 419 (1793).

35. Id. at 430 (Iridell, J., dissenting).

36. Id. at 470 (opinion of Jay, J.). Georgia filed papers contesting jurisdiction, but refused to participate in oral argument before the Court. Id.

37. Id. at 436 (Iridell, J., dissenting).

38. Id. at 467 (opinion of Cushing, J.).

39. Id. at 479 .

40. Hans v. Louisiana, 134 U.S. 1,11 (1890). Some commentators have argued that because it was drafted to overrule Chisholm, the Eleventh Amendment should be construed to withdraw jurisdiction only in cases like Chisholm; in other words, only when a private plaintiff attempts to invoke the Article III citizen-state diversity jurisdiction. See generally William A. Fletcher, $A$ 
wording the Eleventh Amendment only disallows a federal forum in suits "commenced or prosecuted against one of the United States by Citizens of another State, or by Citizens or Subjects of any Foreign State," jul judicial interpretation has broadened the Amendment's scope far beyond its text. The Eleventh Amendment no longer stands for what it says. Regardless of the phrasing, the Eleventh Amendment's "significance... 'hes in its affirmation that the fundamental principle of sovereign immunity limits the grant of judicial authority in Art. III' of the Constitution." ${ }^{\text {22 }}$

Judicial expansion of the Amendment's meaning dates from the Court's 1890 decision in Hans v. Louisiana. In Hans, the Court held that the Eleventh Amendment barred a suit by an individual against his state of citizenship, the plain text of the Amendment notwithstanding. ${ }^{43}$ Hans, a citizen of Louisiana, sued Louisiana under the Contracts Clause ${ }^{44}$ to recover on bonds the state issued but refused to honor. ${ }^{45}$ The Court noted that its recent decisions established that the sovereign immunity embodied in the Eleventh Amendment extended to suits arising under federal law. ${ }^{46}$ It then asked whether "when the eleventh amendment was adopted, it was understood to be left open for citizens of a state to sue their own state in the federal courts, while the idea of suits by citizens of other states, or of foreign states, was indignantly repelled?"47 Finding such an idea to be "absurdity on its face," the Court held that the Eleventh Amendment barred Hans's suit. ${ }^{49}$

After Hans, the Eleventh Amendment became greater than its text; it grew to "reflect[] 'the fundamental principle of sovereign immunity [that]

Historical Interpretation of the Eleventh Amendment: A Narrow Construction of an Affirmative Grant of Jurisdiction Rather Than a Prohibition Against Jurisdiction, 35 STAN. L. Rev. 1033 (1983) (describing the diversity theory of Eleventh Amendment interpretation). A minority of the Court apparently accepts such an interpretation of the Amendment. Seminole Tribe of Fla. v. Florida, 517 U.S. 44, 110-11 \& n.8 (1996) (Souter, J., dissenting) (espousing diversity interpretation); Fitzpatrick v. Bitzer, 427 U.S. 445, 457 (1976) (Brennan, J., concurring in the judgment) (rejecting Connecticut's Eleventh Amendment defense against a suit by its own citizens because the "Amendment bars only federal-court suits against States by citizens of other States"). However, a majority of the Court rejects the diversity interpretation outright in favor of the broad sovereign immunity theory espoused in Hans. Seminole Tribe, 517 U.S. at 68 (rejecting diversity interpretation espoused by dissent as "a theory cobbled together from law review articles and its own version of historical events").

41. U.S. Const. amend. XI.

42. Atascadero State Hosp. v. Scanlon, 473 U.S. 234, 238 (1985) (quoting Pennhurst State School \& Hosp. v. Halderman, 465 U.S. 89, 98 (1984)).

43. Hans, 134 U.S. at 15.

44. U.S. CoNST. art. I, $\S 10$ (providing in relevant part that "[n]o State shall . . pass any ... Law impairing the Obhigation of Contracts ...").

45. Hans, 134 U.S. at 1.

46. Id. at 10.

47. Id. at 15 .

48. Id.

49. Id. at 21 . 
limits the grant of judicial authority in Art. III ...." 50 Despite the broad immunity granted the states, until recently several effective mechanisms remained for Congress or individual litigants to enforce federal rights against unconsenting states in the federal courts. These included legislative abrogation of Eleventh Amendment immunity, ${ }^{51}$ prospective injunctive relief against state officers under the doctrine of Ex Parte Young, ${ }^{52}$ and the implied waiver doctrine of Parden v. Terminal Railway. ${ }^{53}$ The Court's recent decisions in Seminole Tribe, College Savings Bank, $^{54}$ and Alden v. Main ${ }^{55}$ have left Congress all but powerless to subject states to suits by private citizens to enforce federal law, includimg federal patent law. ${ }^{56}$ The next subsections will discuss the federal government's dwindling ability to enforce federal law against the states.

\section{B. Seminole Tribe and the Demise of Legislative Abrogation of Eleventh Amendment Immunity}

The Court long allowed Congress to abrogate the states' immunity from suit in federal court for violations of federal law. In Fitzpatrick $v$. Bitzer, ${ }^{57}$ for example, the Court found jurisdiction over a suit by state enployees against the state for violations of Title VII of the Civil Rights Act of $1964 .^{58}$ The Court analogized the case to its earlier decision in Parden, which affirmed Congress's power to subject states to suit for violations of a law passed under the Commerce Clause, ${ }^{59}$ but noted that the statute at issue

50. Seminole Tribe of Fla. v. Florida, 517 U.S. 44, 64 (1996) (quoting Pennhurst State School \& Hosp. v. Halderman, 465 U.S. 89, 97-98 (1984)).

51. See, e.g., Pennsylvania v. Union Gas Co., 491 U.S. 1 (1989) (plurality opinion), overruled by Seminole Tribe, 517 U.S. 44; Fitzpatrick v. Bitzer, 427 U.S. 445 (1976) (holding that Congress may abrogate the Eleventh Amendment when legislating pursuant to its enforceinent power under the Fourteenth Amendment).

52. 209 U.S. 123 (1908).

53. 377 U.S. 184, 192-93 (1964) (holding that Eleventh Amendment immunity may be imphedly waived by knowingly engaging in activity regulated by Congress). In Parden, the Court held that Alabama consented to suit under the Federal Employers' Liability Act (the "FELA") when it began operating a railroad twenty years after the FELA had been enacted. Id. at 192. The Court reasoned that Congress had conditioned the right to operate all railroads on amenability to suit under the FELA, and despite its status as a state, Alabama should be treated no differently. Id. Thus, although Alabama did not expressly waive its immunity under the FELA, it impliedly or constructively waived it by running the railroad.

54. 527 U.S. 666 (1999) (rejecting the constructive waiver doctrine and expressly overruling Parden to hold that waiver of Eleventh Amendment immunity must be express).

55. 527 U.S. 706 (1999) (holding that Congress may not require state courts to hear a federal claim over which the federal courts have no jurisdiction as a result of Eleventh Amendment immunity from suit).

56. For a discussion of the potential impact of Seminole Tribe on enforcement of the federal patent law, see John T. Cross, Intellectual Property and the Eleventh Amendment After Semimole Tribe, 47 DePaul L. Rev. 519 (1998).

57. 427 U.S. 445 (1976).

58. Id. at 456 .

59. Parden v. Terminal Ry. of Ala. State Docks Dep't, 377 U.S. 184, 192 (1964). 
in Fitzpatrick was passed under Congress's power to enforce the Fourteenth Amendment. ${ }^{60}$ After describing the way the Fourteenth Amendment altered the balance of power between the states and the federal government, ${ }^{61}$ the Court rejected the state's Eleventh Amendment defense, holding that "the Eleventh Amendment, and the principle of state sovereignty which it enbodies, are necessarily limited by the enforcenent provisions of $\S 5$ of the Fourteenth Amendment." 62

In Seminole Tribe, the Rehnquist Court abruptly terminated Congress's Article I power to abrogate the states' Eleventh Amendment immunity from suit in federal court. ${ }^{63}$ Seminole Tribe overruled the Court's plurality decision in Pennsylvania v. Union Gas Co. ${ }^{64}$ which held that Congress's authority to regulate interstate commerce gave it the power to subject states to suit for damages under CERCLA. ${ }^{65}$ The Union Gas plurality rested its decision on the fact that in ratifying the Constitution, the states relinquished as inuch of their authority as was necessary to create the federal government. ${ }^{66}$ Although it acknowledged that it had never before squarely decided whether Article I gives Congress the power to abrogate sovereign immunity, ${ }^{67}$ the Court noted that its previous decisions, especially Parden and Employees v. Missouri Department of Public Health \& Welfare, ${ }^{68}$ clearly deinonstrated that "the power to regulate commerce includes the power to override States' immunity froin suit...."69 The Court limited the reach of its decision by holding that it would not find abrogation unless Congress clearly expressed its desire to override sovereign immunity. ${ }^{70}$

It was under the authority of Union Gas that Congress enacted the Patent Reinedy Act, which provided a clear statement of its intent to abrogate states' Eleventh Amendment immunity from suit under the Patent Act. The Patent Remedy Act was thought necessary to comply with the Court's holding in Atascadero State Hospital v. Scanlon, ${ }^{71}$ that "Congress may abrogate the States' constitutionally secured immunity from suit in federal

60. Fitzpatrick, 427 U.S. at $452-53$.

61. Id. at $453-55$.

62. II. at 456 (citation omitted).

63. Id. at 72-73 (holding that "[t]he Eleventh Amendment restricts the judicial power under Article III, and Article I cannot be used to circumvent the constitutional limitations placed upon federal jurisdiction").

64. 491 U.S. I (1989).

65. Id. at 23 .

66. Id. at 19 ("We have recognized that the States enjoy no immunity where there has been 'a surrender of this immunity in the plan of the convention." (quoting Monaco v. Mississippi, 292 U.S. 313, 322-23 (1934) (citations omitted))).

67. Id. at 14 .

68. 411 U.S. 279 (1973).

69. Union Gas, 491 U.S. at 14.

70. Id. at 15 .

71. 473 U.S. 234 (1985). 
court only by making its imtention unmistakably clear in the language of the statute."72 Following Atascadero, the Court of Appeals for the Federal Circuit dismissed a patent infringement suit by an imventor against the state of California, because the Patent Act did not contain a clear statement of intent to abrogate. ${ }^{73}$ That case, Chew v. California, ${ }^{74}$ was cited prominently in the congressional debates leading up to passage of the Patent Remedy Act. ${ }^{75}$ The Federal Circuit later held that the Patent Remedy Act cured the defect found in Chew, and properly abrogated states' sovereign immunity from suit under the Patent Act. ${ }^{76}$ The Patent Remedy Act would have effectively cured the problem of holding state universities accountable for patent infringement, were it not for the Court's decision in Seminole Tribe, which aggressively expanded the scope of Eleventh Amendinent immunity. ${ }^{77}$

In one stroke, Seminole Tribe elimmated Congress's ability to abrogate sovereign immunity using its Article I powers, including those arising under the Patent Clause. ${ }^{78}$ Seminole Tribe involved a suit by an Indian tribe against the State of Florida to enforce provisions of the Indian Gaming Regnlatory Act, ${ }^{79}$ which was passed under the Indian Commerce Clause. ${ }^{80}$ The Court reiterated the rule that to abrogate sovereign immunity Congress must make its intent clear from the language of the statute, and it must pass the statute "pursuant to a valid exercise of power." "The Court found Congress's statement of intent adequately unequivocal. ${ }^{82}$ However, it expressly overruled Union Gas to hold that Article I gives Congress no power to abrogate Eleventh Amendment immunity from suit. ${ }^{83}$

The Court explicitly rejected the reasoning in Union Gas that Congress's plenary power to regulate imterstate commerce necessitated a correspondimg reduction in the sovereignty of the states in that area. ${ }^{84}$ The Court noted that its decision "reconfirm[s] that the background principle of

72. Id. at 242 .

73. Chew v. California, 893 F.2d 331, 334 (Fed. Cir. 1990).

74. Id.

75. H.R. REP. No. 101-960, pt. 1, at 7 \& n.20 (1990).

76. Coll. Savings Bank v. Fla. Prepaid Postsecondary Educ. Expense Bd., 148 F.3d 1343, 1347 (Fed. Cir. 1998) [hereinafter Florida Prepaid I], rev'd 527 U.S. 627 (1999) ('In response to our decisions in Jacobs Wind and Chew, Congress amended the patent laws to express unambiguously its intent to abrogate the sovcreign immunity of the states.").

77. See generally Meltzer, supra note 30 (discussing the broad implications of Seminole Tribe for the federal government's ability to ensure state compliance with federal law).

78. U.S. ConsT. art. I, $\S 8$, cl. 8 (giving Congress the power "[t]o promote the Progress of Science... by securing for limited Times to... Inventors the exclusive Right to their... Discoveries ...").

79. Seminole Tribe of Fla. v. Florida, 517 U.S. 44, 51-52 (1996).

80. U.S. CoNST., art. I, $\$ 8$, cl. 3 .

81. Seminole Tribe, 517 U.S. at 55 (quoting Green v. Mansour, 474 U.S. 64, 68 (1985)).

82. Id. at 56-57.

83. Id. at 66 .

84. Id. at 61,66 . 
state sovereign immunity embodied in the Eleventh Amendment is not so ephemeral as to dissipate when the subject of the suit is an area ... under the exclusive control of the Federal Government." reasoning on the idea that the Framers did not intend for the Constitution to diminish the preexisting sovereign immunity of the states. ${ }^{86}$ The Eleventh Amendment embodies preexisting sovereign immunity and bars Congress from authorizing private suits against states in federal court. ${ }^{87}$ Justice Stevens, in dissent, pointed out the broad reach of the majority's holding, noting that the decision would withdraw from federal court a variety of cases, "from those sounding in copyright and patent law, to those concerning bankruptcy, environinental law, and the regulation of our vast national economy."88

Despite its broad holding, the Seminole Tribe majority specifically reaffirmed the holding im Fitzpatrick that Congress may abrogate sovereign immunity when enacting legislation to enforce the Fourteenth Amendment. ${ }^{89}$ This raised hopes that the Patent Remedy Act could be sustained as legislation passed to enforce the Fourteenth Amendment's guarantee that no "[s]tate shall ... deprive any person of ... property, without due process of law. ${ }^{990}$ The Federal Circuit confirmed these hopes, holding in Florida Prepaid I that the Patent Remedy Act constituted appropriate legislation to remedy state deprivations of patentees' property without due process.91

The Supreme Court granted certiorari ${ }^{92}$ and reversed, holding that neither the Commerce Clause, ${ }^{93}$ the Patent Clause, ${ }^{94}$ nor the Fourteenth Amendment ${ }^{95}$ gave Congress the power to subject unconsenting states to

85. Id. at 72 .

86. Id. at 67-69. Chisholm v. Georgia, decided by a Court whose members actually remembered the framing of the Constitution, held exactly the opposite: that by its express terms Article III authorizes suits by an individual against a state, and that such suits comport with the spirit of the Constitution. 2 U.S. 419, 473-77 (1793). The majority dismissed Chisholm as a decision "contrary to the well-understood meaning of the Constitution." Seminole Tribe, 517 U.S. at 69.

87. Seminole Tribe, 517 U.S. at 72.

88. Id. at 77 (Stevens, J., dissenting).

89. Id. at $71 \mathrm{n} .15$.

90. U.S. CoNST. amend. XIV, § 1; see also Cross, supra note 56, at 527-31. Section 5 of the amendment empowers Congress "to enforce, by appropriate legislation, the provisions of this article." U.S. CoNST. amend. XIV, $\$ 5$.

91. 148 F.3d 1343, 1352 (Fed. Cir. 1998). In contrast to the Federal Circuit's holding, courts examining an analogous issue in copyright and Lanham Act suits held that Congress's attempts to abrogate sovereign immunity from suits under those laws could not be sustained as appropriate legislation to enforce the Fourteenth Amendment. Chavez v. Arte Publico Press, 157 F.3d 282 (5th Cir. 1998) (copyright), reh'g granted, 178 F.3d 281 (5th Cir. 1998); Coll. Savings Bank v. Fla. Prepaid Postsecondary Educ. Expense Bd., 131 F.3d 353 (3d Cir. 1997) (Lanham Act).

92. Fla. Prepaid Postsecondary Educ. Expense Bd. v. Coll. Savings Bank, 525 U.S. 1064 (1999).

93. Florida Prepaid II, 527 U.S. 627, 635-36 (1999).

94. Id.

95. II. at $645-47$. 
suit in federal court for patent infringement. The Court's holdings with respect to the Commerce and Patent Clauses were unsurprising in hight of its holding in Seminole Tribe. Both College Savings Bank and the United States, which had intervened to defend the Patent Remedy Act, conceded early on that the Act could only be sustamed under the Fourteenth Amendment or the constructive waiver doctrine of Parden. ${ }^{96}$

The Florida Prepaid II Court's Fourteenth Amendinent analysis shed light on the new and more stringent requirements necessary for Congress to pass legislation designed to enforce the Amendment. Citing its recent decision in City of Boerne v. Flores, ${ }^{97}$ the Court reaffirmed that "for Congress to invoke $\S 5$, it must identify conduct transgressing the Fourteenth Amendinent's substantive provisions, and must tailor its legislative scheme to remedying or preventing such conduct. ${ }^{298}$ The Court acknowledged that patents constituted property within the meaning of the Fourteenth Amendinent. ${ }^{99}$ However, it found the Patent Remedy Act's "indiscriminate scope" to be wholly disproportionate to the danger of state infringement. ${ }^{100}$ Relying on City of Boerne, ${ }^{101}$ the Court scrutinized the congressional record for evidence of state infringement to determine whether the Act's scope was tailored appropriately. The Court concluded that "Congress identified no pattern of patent infringement by the States, let alone a pattern of constitutional violations" that could justify the Patent Remedy Act. ${ }^{102}$ Justice Stevens, in dissent, noted the unfairness of "strik[ing] down Congress' Act based on an absence of findings supporting a requirement this Court had not yet articulated."103 The Court also noted that Congress failed to examine possible state law remedies for infringement. ${ }^{104}$ Only the unavailability of adequate state law remedies for the patentee triggers a due process violation by the state. Therefore, Congress must examine whether

96. The Parden doctrine recognizes that a state may waive its immunity by knowingly engaging in an activity subject to federal regulation. See infra text accompanying notes 122-132.

97. 521 U.S. 507 (1997).

98. Florida Prepaid II, 527 U.S. at 639.

99. Id. at 640 .

100. Id. at 647 .

101. 521 U.S. at 530-31. The Court relied on City of Boerne for the proposition that Congress should specifically identify a pattern of violations sufficient to sustain the remedial legislation. Florida Prepaid II, 527 U.S. at 639-40. In reality, however, City of Boerne does not support the Court's new requirement. In City of Boerne, the Court did scrutinize the legislative record for examples of state violations of the Establishment Clause. 521 U.S. at 530-31. However, the Court did so to buttress its holding that Congress's concem in passing the Religious Freedom Restoration Act (RFRA), the statute at issue in City of Boerne, was not directed at remedying or preventing constitutional violations. Id. at 531. The absence of any state violations demonstrated to the Court that Congress intended the RFRA to create new substantive rights under the Establishment Clause rather than to enforee existing rights under the Fourteenth Amendment. Id.

102. Florida Prepaid II, 527 U.S. at 640.

103. Id. at 654 (Stevens, J., dissenting).

104. Id. at 643-45. 
the states have provided remedies to the patentee in order to determine whether there are any possible violations for them to remedy.

The majority also found the possibility of holding states liable for negligent infringement to be a particularly egregious disproportionality, since a long line of cases had held that only willful misconduct violates the Fourteenth Amendinent. ${ }^{105}$ Under that line of cases, negligent infringement of a patent would not give rise to a violation that Congress could remedy by passing legislation under section $5{ }^{106}$ As the dissent noted, however, the Court created the negligent/willful distinction to "stem the tide" of litigation by prisoners for negligent imjuries inflicted by state prison officials. ${ }^{107}$ Such actions threatened to overwhelin the federal courts with what were essentially state tort actions that had been constitutionalized under the Fourteenth Amendinent. ${ }^{108}$ The negligent/willful distinction may simply be irrelevant outside the prisoner context. Moreover, most patent infringement suits allege willful infringement, so the problem of suing a state actor for negligent infringement is unlikely to occur. ${ }^{109}$

Thus, Florida Prepaid II effectively closes the door to future legislative attempts to abrogate state immunity from suit for patent infringement. It is possible that Congress could amend the Patent Reinedy Act to eliminate liability for negligent infringement, and it could certainly examine the lack of state law remedies for patent infringement. ${ }^{110}$ However, the requirement that Congress identify a pattern of state infringement likely will undercut future attempts to justify abrogation of immunity under the Fourteenth Amendinent.111 Thus, extracting an express waiver from the states remains the most likely method for ensuring that state universities remain accountable for violations of the patent law.

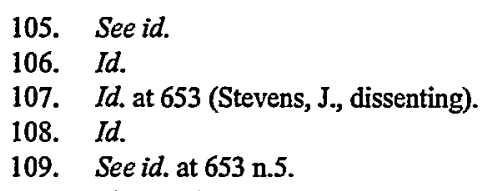

110. The requirement that Congress examine state law remedies is singularly ironic, given the fact that the federal courts have exclusive jurisdiction over suits arising under the Patent Act. See 28 U.S.C. $\S 1338$ (a) (1994). Moreover, the Court has previously forbidden states from legislating in the federally preempted area of patent law. See, e.g., Bonito Boats, Inc. v. Thunder Craft Boats, Inc., 489 U.S. 141, 168 (1989) (holding that Florida law protecting unpatented boathull designs impermissibly entered an area of regulation reserved to Congress); Sears, Roebuck \& Co. v. Stiffel Co., 376 U.S. 225, 231-32 (1964) (holding that state unfair coinpetition law cannot protect against copying an invention which was unprotectable under federal patent law).

111. Florida Prepaid II, 527 U.S. at 627, 641 (finding that states generally respect patent rights, and noting that "[e]ven the [Patent Remedy Act's] sponsor conceded that 'we do not have any evidence of massive or widespread violation of patent laws by the States either with or without this State immunity"' (quoting Patent Remedy Clarification Act: Hearing on H.R. 3866 Before the Subcomm. on Courts, Intellectual Property, and the Administration of Justice, House Comm. on the Judiciary, 101st Cong. 22 (1990) (statement of Rep. Kastenmeier))). However, if state universities decide to take advantage of the ruling in Florida Prepaid II by liberally infringing patent rights, they might create the pattem of misconduct required to sustain legislation under the Fourteenth Amendment. 


\section{College Savings Bank and the Demise of Parden's Constructive Waiver Doctrine}

Unlike other defects in subject matter jurisdiction, sovereign immunity from suit can be waived. ${ }^{112}$ Indeed, the federal government consented long ago to suit in the Court of Claims for patent infringenent. ${ }^{113}$ In Clark $v$. Barnard, the Court considered Rhode Island's claim of Eleventh Amendment immunity after the state had intervened to press its claim to the funds at issue in the suit. ${ }^{114}$ The Court rapidly disposed of Rhode Island's defense, holding that its voluntary intervention in the lawsuit constituted an effective waiver. ${ }^{115}$ The Court described sovereign immunity as "a personal privilege which [the state] may waive at pleasure."116

A state can expressly waive its immunity from suit by so stating in a statute or constitutional provision. ${ }^{117}$ To constitute effective waiver, the statement must contain "an unequivocal indication that the State intends to consent to federal jurisdiction that otherwise would be barred by the Eleventh Amendment." 118 The Court has read this requirement extremely strictly, explaining in Edelman v. Jordan ${ }^{119}$ that it will find waiver "only where stated 'by the most express language or by such overwhelming implications froin the text as (will) leave no rooin for any other reasonable construction."'120 Express waiver seems an unsatisfactory route to closing the loophole opened by Florida Prepaid II, both because it requires excruciatingly explicit voluntary consent by every state, and because each state would be at liberty to withdraw its consent at any time. ${ }^{121}$

112. Clark v. Barnard, 108 U.S. 436, 447 (1883); see RichaRd H. FALloN ET AL., HART AND Wechsler's The Federal Courts and The Federal System 1097-1100 (4th ed. 1996). See generally John Evans Taylor, Note, Express Waiver of Eleventh Amendment Immunity, $17 \mathrm{GA}$. L. REV. 513 (1983) (summarizing doctrine of express waiver of Eleventh Amendment immunity). Like other defects in subject matter jurisdiction, however, an Eleventh Amendment defense ean be raised for the first time on appeal. See Edelman v. Jordan, 415 U.S. 651, 678 (1974) (finding that failure to raise the issue at trial did not bar a sovereign immunity defense on appeal because the Eleventh Amendment "sufficiently partakes of the nature of a jurisdictional bar" rather than a pure subject matter bar).

113. 28 U.S.C. $§ 1498$; Florida Prepaid II, 527 U.S. at 664 (Stevens, J., dissenting).

114. 108 U.S. $436,446$.

115. Id. at 447 .

116. Id.

117. Atascadero State Hosp. v. Scanlon, 473 U.S. 234, 238 \& n.1 (1985).

118. Id. at 238 n. 1 .

119. 415 U.S. 651 .

120. Id. at 673 (quoting Murray v. Wilson Distilling Co., 213 U.S. 151, 171 (1909) (alteration in original)).

121. College Savings Bank, 527 U.S. 666, 676 (1999); cf. Beers v. Arkansas, 61 U.S. 527 (1857) (holding that a state may alter at any time the conditions of its consent to be sued in its own courts). In College Savings Bank, Justice Scalia noted that a state may even be able to change the conditions of its consent and apply those changes to pending litigation. 527 U.S. at 647 . However, Beers, the authority he cites for this proposition, involved a state's ability to revoke or change its consent to suit in its own courts, and it may not be applicable in the federal court setting. 61 U.S. at 528 . 
Until the Court's decision last term in College Savings Bank, the constructive waiver doctrine of Parden arguably presented the most attractive method of holding states accountable for patent infringement other than abrogation. ${ }^{122}$ Parden involved personal injury suits by railroad employees brought under the Federal Employers' Liability Act ${ }^{123}$ (the "FELA"). ${ }^{124}$ Unfortunately for the plaintiffs, the employer railroad was owned and operated by the State of Alabama, which claimed the Eleventh Amendment barred enforcement of the FELA against it in federal court. ${ }^{125}$

The Parden Court treated the case as involving a two step analysis: "(1) Did Congress in enacting the FELA imtend to subject a State to suit in these circumstances? (2) Did it have the power to do so, as agaimst the State's claim of immunity?" ${ }^{26}$ The Court answered the first question affirmatively, holding that the extremely broad and allencompassing statutory language demonstrated Congress's desire to hold all railroad carriers liable under the FELA, regardless of ownership by state entities. ${ }^{127}$ The Court apparently thought treating states differently from private market participants for FELA purposes would be illogical and unjust. The Court explained:

It would surprise our citizens, we think, to learn that petitioners, who in terms of the language and purposes of the FELA are on precisely the same footing as other railroad workers, must be demed the benefit of the Act simply because the railroad for whicl they work happens to be owned and operated by a State rather than a private corporation. ${ }^{128}$

Thus, the Court found Congress must have intended to include states within the class of defendants regulated by the FELA.

Turning to the question of Congress's power to subject state entities to FELA suits, the Court reasoned that, in ratifying the Constitution, the states necessarily ceded the part of their sovereignty that affected interstate commerce, because Article I specifically grants Congress power to regulate in that arena. ${ }^{129}$ Thus, the Court held that state sovereign immunity could present no obstacle to a FELA suit. ${ }^{130}$ Although such a finding seems to

122. Even before College Savings Bank, many commentators speculated that Seminole Tribe sufficiently undercut the basis for Parden's holding as to render the constructive waiver doctrine a nullity. See Cross, supra note 56 , at 537.

123. 45 U.S.C. $\$ 51$ (1908).

124. Parden v. Terminal Ry. of the Ala. State Docks Dep't, 377 U.S. 184, 184 (1964).

125. Id. at 185 .

126. Id. at 187 .

127. Id. at $189-90$.

128. Id. at 197 (footnote omitted).

129. Id. at 192 (holding that by "empowering Congress to regulate commerce... the States necessarily surrendered any portion of their sovereignty that would stand in the way of such regulation").

130. Id. 
lead inevitably to the conclusion that Congress abrogated sovereign immunity under the FELA, the Court rejected that view, explaining that "[i]t remains the law that a State may not be sued by an individual without its consent."131 The Court instead held that by entering the field of railroad ownership, which Alabama knew was regulated by Congress under its Commerce Clause authority, Alabama must have intended to waive its immunity from suit under federal laws regulating railroads. ${ }^{132}$ This became known as the theory of constructive waiver, or the Parden doctrine.

Subsequent decisions severely limited, ${ }^{133}$ and finally expressly overruled, ${ }^{134}$ the first prong of Parden. Although attractive from the perspective of individual plaintiffs aggrieved by state action, according to the Court, a rule that would treat states no differently from private market participants ignores the fact that "[s]tates occupy a special and specific position in our constitutional system ...."135 Concerned that the Parden doctrine endangered the constitutional role of the states, in Welch v. Texas Department of Highways \& Public Transportation the Court overruled that portion of Parden inconsistent with a requirement that Congress clearly express its intent to subject states to suit. ${ }^{136}$ Although Justice Scalia would have overruled Parden entirely, ${ }^{137}$ a majority of the Court disagreed. Thus, the portion of Parden allowing Congress power to subject the states to suit remaimed intact.

Although not a case involving waiver, Seminole Tribe cast doubt on the continued validity of the second prong of Parden, which was based on the idea that states ceded sovereignty over activities related to interstate commerce when they ratified the Constitution. Seminole Tribe held that the Eleventh Amendinent restored the states' sovereigu immunity, and therefore Congress could not abrogate sovereign immunity under its Article I powers. ${ }^{138}$ If, under Seminole Tribe, the Eleventh Amendinent restored the

131. Id.

132. Id.

133. See Employees of Dep't of Pub. Health \& Welfare of Mo. v. Dep't of Pub. Health \& Welfare of Mo., 411 U.S. 279, 284-85 (1973) (refusing to find sufficiently precise language of congressional intent to subject states to the statute at issue and distinguishing Parden as a case involving "dramatic circumstances" which "can be put to one side").

134. Welch v. Tex. Dep't of Highways \& Pub. Transp., 483 U.S. 468, 478 (1987) (overruling Parden to the extent that it was "inconsistent with the requirement that an abrogation of Eleventh Amendment immunity by Congress must be expressed in unmistakably clear language...."). Despite the Court's strong admonitions to the contrary, Congress continues to adhere to the behief expressed in Parden that injustice might result from treating states differently than private individuals. S. REP. No. $102-280$, at 9 (1992) ("[T]he current state of the law leaves the protection afforded to patent ... holders dependant on the status of the infringing party. A public school such as UCLA can sue a private school such as USC for patent infringement, yet USC cannot sue UCLA for the same act.").

135. Atascadero State Hosp. v. Scanlon, 473 U.S. 234, 242 (1985) (quoting Garcia v. San Antonio Metro. Transit Auth., 469 U.S. 528, 547 (1985)).

136. Welch, 483 U.S. at 478.

137. Id. at 496 (Scalia, J., concurring in part).

138. Seminole Tribe of Fla. v. Florida, 517 U.S. 44, $72-73$ (1996). 
states' ability to resist suits for violation of laws passed under Congress's Article I powers, then perhaps the Amendment also prevented Congress from using Article I legislation to extract a waiver. Seminole Tribe undercut Parden's rationale to such a degree that the district court in College Savings Bank refused to uphold the Patent Remedy Act on a constructive waiver theory, holding that "in the wake of Seminole Tribe, Congress may no longer utilize its Article I powers to elicit a waiver of sovereign immunity as a condition for participating in a field subject to congressional regulation."139.

The Court's decision last term in College Savings Bank eliminated any lingering doubts as to the continuning vitality of constructive waiver. College Savings Bank involved a suit by a private bank against Florida for violations of the unfair competition prong of the Lanham Act. ${ }^{140}$ Writing for the Court, Justice Scalia attacked Parden's reasoning and precedential value. ${ }^{141}$ He noted that "constructive consent is not a doctrine commonly associated with ... constitutional rights." 142 The Parden doctrine, therefore, conflicts with the requirement expressed in later cases that Congress declare its intent to subject states to suit in statutory text. ${ }^{143}$ Moreover, allowing Parden waivers would produce an end run around Seminole's anti-abrogation primciple. ${ }^{144}$ College Savings Bank also specifically rejects the proposition that fairness requires that states entering federally-regulated markets be treated identically to similarly-situated private market participants. ${ }^{145}$ Apparently, in the sovereign imununity context such evenhandedness "is not to be expected." 146 According to the College Savings Bank majority, "[t]he constitutional role of the States sets them apart," even when they compete head-to-head in the marketplace with private actors who must comply with the federal regulations. ${ }^{147}$

The Court's decision in College Savings Bank casts considerable doubt on the constitutionality of proposals to condition receipt of a patent on waiver of Eleventh Amendment immunity. Senator Leahy has proposed

139. Coll. Savings Bank v. Fla. Prepaid Postsecondary Educ. Expense Bd., 948 F. Supp. 400, 416 (1996), aff'd Coll. Savings Bank v. Fla. Prepaid Postsecondary Educ. Expense Bd., 131 F.3d 353 (3d Cir. 1997) and Florida Prepaid I, 148 F.3d 1343 (Fed. Cir. 1998), and aff'd in part by College Savings Bank, 527 U.S. 666 (1999), and rev'd in part by Florida Prepaid II, 527 U.S. 627 (1999).

140. College Savings Bank, 527 U.S. at 669 . This case involved the same parties and sprang from the same set of facts as Florida Prepaid II. For a discussion of the facts and procedural history of these cases, see Jennifer L. Polse, Note, Florida Prepaid Postsecondary Education Expense Board v. College Savings Bank \& College Savings Bank v. Florida Prepaid Postsecondary Education Expense Board, 15 BERKELEY TECH. L.J. 373 (2000).

141. College Savings Bank, 527 U.S. at 680-81.

142. Id. at 681 (quoting Edelman v. Jordan, 415 U.S. 651, 673 (1974)).

143. Id. at 680 .

144. See id.

145. Id. at $684-86$.

146. Id. at 685 .

147. Id. (quoting Welch v. Tex. Dep't of Highways \& Pub. Transp., 483 U.S. 468, 477 (1987)). 
just such a bill, the Intellectual Property Protection Restoration Act (the "IPPRA"), in Congress. ${ }^{148}$ The IPPRA would condition participation in the federal intellectual property system on an agreement to waive sovereign immunity. ${ }^{149}$ In order to receive any federal property right, mcluding a patent, the state would have to agree to waive its sovereign immunity froin any suit arising under federal intellectual property law during the pendency of the application and the term of the resulting patent. ${ }^{150}$

The IPPRA presents a creative solution to the Florida Prepaid dilemma. The proposed law's approach recalls that of the Federal Circuit in Genentech II, which held that the University had waived its Eleventh Amendınent rights from suits brought to determine the validity of its own patents. ${ }^{151}$ However, the IPPRA suffers froin the same defect that plagues the Federal Circuit's Genentech II decision: College Savings Bank forbids Congress from extracting a waiver of sovereign immunity pursuant to its Article I powers. The IPPRA attempts just what College Savings Bank proscribes: utilization of Congress's Patent Clause powers to force states to waive sovereign immunity.

Nevertheless, the IPPRA could perhaps be defended on the ground that because the federal government need not give states patents at all, it is entitled to place conditions on its decision to allow the state to obtam a patent. This approach analogizes patent rights to grants of government funds under the Spending Clause. Under the Court's interprctation of the spending power, Congress might well be entitled to condition a grant on the state's waiver of sovereign immunity. ${ }^{152}$ However, the broadness of the Court's interpretation of the spending power might put it in a class by itself..$^{153}$ It is not at all certain that the Court would be willing to allow Congress similar broad powers to condition patent grants on waiver of constitutional rights. The idea that Congress possesses such power seems tenuous when viewed in light of the Florida Prepaid II Court's absolute dismissal of the possibility that Congress could abrogate immunity under its Patent Clause powers. ${ }^{154}$ It is difficult to believe that the Florida Prepaid II majority would approve of a Patent Remedy Act that had been redrafted to condition the benefit of receiving a patent on waiver.

148. S. 1835, 106th Cong. (1999); 145 Cong. REc. Sl3555 (daily ed. Oct. 29, 1999) (statement of Sen. Leahy).

149. S. 1835,106 th Cong. $\$ 111$ (1999).

150. Id. $\S 131$ (a). The bill defines federal intellectual property as including copyright, trademark, and patent rights. Application for any one of these rights would require a waiver of sovereign immunity from suit under laws pertaining to all of them. Id.

151. Genentech II, 143 F.3d 1446, 1454 (Fed. Cir. 1998).

152. See infra Part III.

153. Meltzer, supra note 30,51-52 (noting the broad nature of the Court's Spending Clause precedents).

154. Florida Prepaid II, 527 U.S. 627, 635 (1999). 
Where College Savings Bank leaves aggrieved patentees is an open question. The Court is not receptive to the argument that allowing states to accumulate and enforce their own patent rights, while removing private litigants' abilities to protect their intellectual property rights against those same states, is simply unjust. Justice Scalia's opinion im College Savings Bank sounded the death knell for fairness arguments in the sovereign immunity context. ${ }^{155}$ Therefore, if Congress wishes to safegnard the rights of patentees and retain the imcentives it created for state universities to accumulate patent rights, it must find a more technical way around the Eleventh Amendment.

II

\section{The Bayh-Dohl Act and the Role of State Universities in the PATENT System}

When Jonas Salk imvented the polio vaccine, he did it for the good of lumanity, not for a property right. When asked who owned his invention, "Salk fainously replied: 'There is no patent. Could you patent the sun?"'156 His attitude and approacli to researcli typified the pre-Bayli-Dohl Act era of academic researcli. ${ }^{157}$ And although that era produced many useful inventions, including Salk's, Congress grew dissatisfied with the rate at which government-funded researcli resulted in fully realized inventions available for public use. ${ }^{158}$ Instead of being developed by private industry, academic inventions languislied unused, or worse yet from Congress's perspective, were developed by foreign rather than domestic industry. ${ }^{159}$ Congress

155. College Savings Bank, 527 U.S. 666, 686 (1999).

156. Scott LaFee, Smart Money: In Science Today, the Question Is: Who Will Own Your Next Great Idea?, SAN DIEGo UNION-TRIB., Mar. 24, 1999, at E1, available at 1999 WL 4059246.

157. See id.; Duecker, supra note 21, at 455; Rebecca S. Eisenberg, Proprietary Rights and the Norms of Science in Biotechnology Research, 97 YALE L.J. 177, 182 (1987).

158. Patent Issues in Federally Funded Research: Hearings on the Bayh-Dohl Act Before the Judiciary Subcomm. on Patents, Copyrights and Trademarks, House Comm. on the Judiciary, 103d Cong. (1994) [hereinafter Hearings] (statement of Sen. Birch Bayh), available at 1994 WL 14185684. Discussing the impetus for the bill before the Senate Judiciary Committee, Senator Bayh noted that before its passage:

while the United States government was spending almost $\$ 30$ billion a year for research and development the results of these efforts almost never found their way into the marketplace. The taxpayers were getting almost no return on their investment. We came to the realization that this failure to move from abstract research into useful commercial innovation was largely a result of the government's patent policy and we sought to draft legislation which would clrange this policy in a way to quickly and directly stimulate the development and commercialization of inventions.

Id.

159. In many cases when a patent did issue on the technology, the federal government retained title to the inventions. It was taken for granted that "if tax dollars paid for the research behind an invention... the government slould own it." Dueker, supra note 21, at 460 . However, the federal government proved notoriously difficult to contract with regarding property rights, and thus these government-owned inventions never resulted in products that would vindicate the public tax inoney spent to produce the imitial research. See id. at 460-61. 
thought that without the ability to exclude others from selling the completed product, private industry lacked incentives to shepherd an academic invention through the expensive later stages of developinent and marketing. ${ }^{160}$ For their part, universities argued that if they retained title to their inventions, they could better facilitate technology transfer through licensing agreements with private industry. ${ }^{161}$

The Bayh-Dohl Act addressed the technology-transfer problem by allowing inventors or their research institutions to seek and retain title to patents on their inventions. The Act declares that:

It is the policy and objective of the Congress to use the patent system to promote the utilization of inventions arising from federally supported research or development;... to promote collaboration between commercial concerns and nonprofit organizations, including universities;... to promote the commercialization and public availability of inventions made in the Umited States by Uirited States industry and labor . . . ${ }^{162}$

The Bayh-Dohl Act meets these goals by giving mventors property rights in their inventions, and by allowing them to grant exclusive licenses to practice the invention. ${ }^{163}$

The Bayh-Dohl Act has been remarkably successful at spurring development of federally funded inventions developed at research universities. Umiversities now actively accumulate patents and vigorously court potential licensees. ${ }^{164}$ Indeed, umiversities now count the size of their patent portfolio as one indicator of prestige. ${ }^{165}$ The race to the patent office is not confined to universities located in technology powerhouse states like California. State university systems that perceive theinselves to be behind in the race are now revising their patent and technology transfer policies to encourage their faculty to patent more inventions. ${ }^{166}$

160. Eisenberg, supra note 21, at 1698-99.

161. Id. at 1700 .

162. 35 U.S.C. $\$ 200$ (1984).

163. Hearings, supra note 158.

164. Dueker, supra note 21 , at $465-66$. The University of California is a case in point. 1ts Office of Technology Transfer Web site boasts that:

At the present time, the University has over 2,000 inventions that have commercial value and are available for licensing. These inventions span many fields including health care and biotechnology, chemicals and advanced materials, computers, electronics and engineering, and more. The University currently has over 600 active licenses in place and einploys over 60 licensing professionals who are skilled at working with industry to arrive at approaches to commercializing the University technology that ineet the needs of both the University and its industrial partners.

Office of Technology Transfer, Opportunities for University/Industry Technology Transfer, available at http://www.ucop.edu/ott/workuc.html (visited Mar. 8, 2000).

165. See Tanya Schevitz, UC Is Top U.S. University for Patents, S.F. CHRON., Oct. 26, 1999, at A18, available at 1999 WL 2699059.

166. See, e.g., Beverly Medlyn, Regents Revise Patent Policy at Universities, ARIz. RePuBlic, June 26, 1999, at B1, available at 1999 WL 4181117. 
Moreover, although the Bayh-Dohl Act did not expressly intend to produce a licensing windfall for universities, it did have that effect. ${ }^{167}$ The University of Cahifornia, which possesses the most patents of any U.S. university, received $\$ 88.5$ million in patent royalties and licensing fees in the 1997-98 fiscal year. ${ }^{168}$ Of course, thanks to licensing, university research-much of it by state universities like the Uiviversity of California-has generated products that benefit U.S. industry and society in general. ${ }^{169}$ Gatorade, for example, sprang from an invention by researchers at the University of Florida; ${ }^{170}$ the hepatitis- $B$ vaccine grew out of researcli at the University of California; ${ }^{.171}$ and the anticancer drug cisplatin was invented by researclers at Michigan State. ${ }^{172}$

The rising investment by universities in the patent system has sparked an inevitable increase in the amount of patent hitigation involving those universities. ${ }^{173}$ The increase stems, in part, from the frequency with whicl technology licensing breaks down into disputes between licensor and licensee. ${ }^{174}$ The rate of disputes may be even higher in the university context, both because university patents present relatively high-risk investments for private industries, ${ }^{175}$ and because the university culture of openness often clashes with the highly protective attitude private industry adopts towards its intellectual property. ${ }^{176}$

The Court's decision in Florida Prepaid II that the Eleventh Amendment bars suits in federal court agamst unconsenting states under the patent law ${ }^{177}$ bodes ill for the ability of patentees and accused infringers to protect their rights agamst state universities. The opportunity Florida Prepaid II creates for state university researchers to infringe patents in

167. See Dueker, supra note 21 , at 453 (noting that licensing of their intellectual property has generated more than $\$ 20$ billion dollars in revenue for universities that engage in technology transfer).

168. Schevitz, supra note 165 , at A1.

169. Dueker, supra note 21 , at 455.

170. Medlyn, supra note 166.

171. Schevitz, supra note 165 .

172. Dueker, supra note 21 , at 455 .

173. For example, last year the University of Minnesota reaped a $\$ 300$ million settlement in its suit against pharmaceutical giant Glaxo-Wellcome, and in 1999 Genentech agreed to pay the University of California $\$ 200$ million to settle the hGH dispute described in the Introduction to this Comment. Steven Andersen, Eureka! University Strikes Licensing Mother Lode with Record Tech Transfer Settlement on AIDS Drug, CORP. LEGAL TIMES, Jan. 2000, at 68. Meanwhile, the State of Califomia has decided to create a central office to exploit and protect state and state-university owned intellectual property rights. Catherine Bridge, Officials Look at Protecting California IP, THE RECORDER, Nov. 9 1999 , at 1.

174. See Norman H. Zivin \& Wendy E. Miller, An Overview of a Patent Suit and the Decision to File, 320 PLI/P 81, 89 (1991).

175. Michael Lytton, US: Avoiding Common Pitfalls: Licensing New Biotech Inventions-Palmer \& Dodge LLP, MondaQ Bus. BriefIng, Sept. 8, 1999, available at 1999 WL 8711360.

176. See Hayden R. Brainard, Survey and Study of Technology Development and Transfer Needs in New York, 9 ALB. L.J. ScI. \& TECH. 423, 437-38 (1999).

177. Florida Prepaid II, 527 U.S. 627, 645 (1999). 
their quest for new inventions has not been lost upon university technology transfer offices. ${ }^{178}$ The potential exists for state universities to exploit their immunity, thereby increasing the profitability of their technology portfolios.

The Eleventh Amendment presents no bar to a state bringing its own infringement action, and there is reason to believe state universities will vigorously defend their property rights. State universities have been active and successful litigators. ${ }^{179}$ Indeed, one commentator has argued that university expertise in litigation disadvantages the small businesses and entrepreneurs that the Bayh-Dohl Act singled out as ideal recipients of exclusive licenses for federally funded inventions. ${ }^{180}$ The quantity of hitigation involving university research activities will likely grow, as universities work to protect and expand their valuable patent portfolios. And, as the Genentech case demonstrates, the Eleventh Amendment provides a potent-and perhaps unfair-strategic tool for state universities contemplating an infringement action against private industry.

The profitability of patents may create incentives for university researchers to pursue studies directed towards industrially viable imventions, thus increasing the likelihood that researchers will infringe existing privately held patents. ${ }^{181}$ Particularly im the biotechnology area, such infringement may consist of using patented technology to create new inventions. Protection of a patentee's rights, therefore, ideally would involve suing a university for damages for infringing research activity. ${ }^{182}$ Conversely, the presence of a university-owned patent of questionable validity might deter potentially mfringing research unless the would-be researchers can file a declaratory judginent action to determine the patent's validity.

178. See Scott D. Stimpson \& James S. Mcdonald, Universities Discover Patents: Great Potential, But Managers Must Beware of Pitfalls, N.Y. L.J., Jan. 18, 2000, at S6.

179. Genentech I, 998 F.2d 931, 935 (Fed. Cir. 1993), described in the Introduction to this Comment, is one example. Such litigation can result in hefty settlements for a state university. See, e.g., Kristin Gustafson, U. Minnesota: New U. Minnesota Policy to Protect School's Intellectual Property, U-WIRE, Oct. 8, 1999, available at 1999 WL 18817750 (describing a $\$ 300$ million settlement obtained by the University of Minnesota for settling its patent dispute with Glaxo-Wellcome).

180. Brainard, supra note 176 , at 433,457 .

181. Regulations promulgated nnder the Bayh-Dohl Act require universities to funnel a percentage of the royalties back to the individual inventor. See, e.g., 37 C.F.R. $\S 401.14(\mathrm{k})(2)(2000)$. This requirement creates increased incentives for directing research towards patentable products. The incentive-shift away from basic research created by such a system was one reason academics initially distrusted pursuing patent rights. See Dueker, supra note 21, at 464-65. Nowadays, in addition to licensing their inventions to existing industries, many academics in the biomedical field thoroughly embrace the profit-motive by creating their own companies to license and develop their patents. See Stolberg, supra note 21, at A-9.

182. Professor Eisenberg has noted that in many such eases a suit for damages might be the patentee's only recourse, because the ultimate product that the university licenses to a private industry does not itself infringe. Rebecca S. Eisenberg, A Technology Policy Perspective on the NIH Gene Patenting Controversy, 55 U. PITT. L. REV. 633, 646 (1994). 
Perhaps the most troubling aspect of state university unaccountability for patent infringement is the effect such immunity might exert on the incentive structure of the Bayh-Dohl Act. The successfulness of the Act depends on universities licensing their technology to private industry. A private coinpany might be deterred froin entering such licensing negotiations if it knows in advance that there is no easy way to loold the university accountable for patent infringenent disputes that might ensue. This concern is particularly valid given the high probability that such a licensing arrangeinent might disintegrate into litigation. ${ }^{183}$ Deterring such technology transfer arrangeinents would undermine the Bayli-Dohl Act's goal of encouraging developinent of federally funded inventions.

Congress's response to the specter of unaccountable state infringeinent of federal property rights might create additional threats to the Bayl1-Dohl Act's incentive structure. Florida Prepaid II has generated congressional interest in withholding patent rights entirely unless the state waives its immunity froin suit under the patent law. Whether such an approacl would convince states to waive their immunity is an open question. However, for those states that choose not to waive their sovereign immunity, such a regime would prevent their universities from assisting in the development of federally funded inventions. ${ }^{184}$ This sclieme would recreate the very problem the Bayh-Dohl Act was supposed to prevent.

The potential threat to future developinent of federally funded inventive activity necessitates a careful legislative response to Florida Prepaid II. Simply withholding patent rights from state universities might result in fewver highly beneficial inventions reaching the public. Even if researchers continue to invent, they will have no ability to license their invention to private industry, and universities lack the institutional capacity to market inventions themselves. ${ }^{185}$ Part III of this Comment suggests that conditioning receipt of federal research funding on waiver of sovereign immunity from patent suits resulting froin university research presents the inost viable inethod for overcommg the Florida Prepaid II problem. Sucli an approacli would most likely pass constitutional muster, and would not disturb the Bayh-Dohl Act's incentive structure.

183. See Zivin \& Miller, supra note 174 .

184. This scenario assumes that failure to pursue a patent on a federally funded invention, which results in the invention entering the public domain, would prevent or significantly deter development of the invention. Although this assumption underlies the Bayh-Dohl Act and much of current federal policy towards funded research, it is not without its critics. See generally Eisenberg, supra note 21. Also, if the state university cannot obtain a patent, the federal government can exercise its right to do so, thus securing the abihty to license the invention to private industry.

185. Id. at 1698 . 
III

Holding Universities Accountable for Patent Infringement by Conditioning Receipt of Government Research Grants on WaIVER of Sovereign IMmunity from the Patent LaWs

Use of the spending power presents the most viable option for holding state universities accountable for violations of the patent law. Article I gives Congress the power to "lay and collect Taxes, Duties, Imposts and Excises, to pay the Debts and provide for the common Defence and general Welfare of the United States." 186 The Suprene Court has interpreted this power expansively. Within broad limits, Congress may establish conditions on receipt of federal grants to promote the general welfare. ${ }^{187}$ The Court has consistently held that Congress may achieve objectives through use of the spending power that it cannot achieve through direct regulation. ${ }^{188}$ Congress might, therefore, condition state university receipt of federal research grants, which fund large portions of university research, ${ }^{189}$ on the state waiving its sovereign immunity from suit under the patent law for research activities at the universities. Such a plan would ensure that federally funded research activities remain patentable by the researchers, thus safeguarding the objectives of the Bayh-Dohl Act. Moreover, it would help assure potential licensees of federal research, as well as other private researchers in the field, that they will be able to meet the state university on a level playing field should litigation become necessary.

The Court sketched the general contours of a valid conditional spending grant in South Dakota v. Dole. ${ }^{190}$ The Dole Court confronted a challenge to a federal highway grant conditioned upon the state adopting a minimum drinking age of twenty-one years. ${ }^{191}$ South Dakota, which allowed nineteen year olds to purchase $3.2 \%$ beer, contended that the condition invaded its constitutional right to regulate alcohol sales secured under the Twenty-first Amendinent. ${ }^{192}$ The Court refused to analyze the case within the framework of the Twenty-first Amendinent, because it determined that Congress was not attempting to regulate directly under the

186. U.S. ConsT. art I, § 8, cl. 1 .

187. For an overview of the spending power and a theory on its limitation, see generally Albert J. Rosenthal, Conditional Federal Spending and the Constitution, 39 STAN. L. Rev. 1103 (1987).

188. South Dakota v. Dole, 483 U.S. 203, 207 (1987) (noting that "objections not thought to be within Article I's 'enumerated legislative fields' may nevertheless be attained through the use of the spending power ..." (quoting United States v. Butler, 297 U.S. 1, 65 (1936))); United States v. Butler, 297 U.S. 1, 66 (1936) (noting that "the power of Congress to authorize expenditure of public moneys for public purposes is not limited by the direct grants of legislative power found in the Constitution").

189. Dueker, supra note 21, at 453.

190. 483 U.S. 203 (1987).

191. Id. at 205.

192. U.S. CoNST. amend. XXI, $\$ 2$ provides that "transportation or importation into any State, Territory, or possession of the United States for delivery or use thereni of intoxicating liquors, in violation of the laws thereof, is hereby prohibited." 
commerce power. ${ }^{193}$ Rather, Congress had used its spending power to try to induce states to conform to a standard minimum drinking age. ${ }^{194}$ Under Dole, indirectly extracting a waiver as a condition of receiving federal research funds might be valid, even though under Florida Prepaid II and College Savings Bank Congress lacks the power to abrogate sovereign inmunity directly or compel a waiver.

Although broad in scope, the spending power is nevertheless subject to several limitations, each of which inust be overcome for a conditional grant to be sustained. ${ }^{195}$ The text of the Spending Clause itself outlines the first condition: the grant inust proinote the "general Welfare."196 This requireinent is particularly easy to meet because the Court gives considerable deference to Congress's judgment on whether an exercise of the Spending Clause promotes the general welfare. ${ }^{197}$ Federal research funds, which aid in the development of useful inventions and contribute to the advanceinent of science, clearly ineet this standard. The second eleinent of the test, that the condition be unambignous, ${ }^{198}$ can be inet quite readily by clear drafting. ${ }^{199}$

The third element, that the condition be germane to the general welfare objective, ${ }^{200}$ remains soinewhat ambignous despite the Dole Court's tepid atteinpt at clarification. Insisting that South Dakota had conceded germaneness, the Dole majority barely addressed the issue. ${ }^{201}$ The Court's soinewhat conclusory analysis began by noting that "the condition imposed by Congress is directly related to one of the main purposes for which highway funds are expended-safe interstate travel."202 Noting that differences in drinking ages can create incentives for youths to drink and drive (since it encourages driving across the border to buy alcohol), the Court found the condition "reasonably calculated" to promote safe highway travel. ${ }^{203}$ Dole seems to require little inore than that behavior inodification by some small subset of the actors affected by the condition-here,

193. Dole, 483 U.S. at 206.

194. Id.

195. Id. at 207-08; Meltzer, supra note 30, at 53-54.

196. U.S. Const. art. I, $\S 8$, cl. 1; Dole, 483 U.S. at 207 (stating requirement and noting its constitutional origins).

197. Dole, 483 U.S. at 207.

198. Id.

199. For example, federal research grants could state unambiguously that by accepting the grant, the university agrees to waive immunity from suit under the Patent Act resulting from activities and discoveries funded by the grant.

200. Dole, 483 U.S. at 207 (noting that "our cases have suggested (without significant elaboration) that conditions on federal grants might be illegitimate if they are unrelated 'to the federal interest in the particular national projects or programs"' (quoting Massachusetts v. United States, 435 U.S. 444, 461 (1978))).

201. Id. at 208.

202. Id.

203. Id. at 209. 
teens who drive drunk after crossing state borders to buy alcohol-will serve the general welfare purpose for the grant.

If the Dole majority's analysis truly represents the rigor with which the Court will enforce the germaneness requirement, then Congress should have no difficulty extracting a waiver of a state university's sovereign immunity from patent lawsuits in exchange for federal research funds. Indeed, there seems no reason to stop with state universities. If the condition need only be reasonably related to Congress's purpose, then why not condition waiver by the entire state on the theory that state universities engage a sizeable proportion of the state's potential violations of the patent law? One commentator has suggested that Dole would allow Congress to condition federal research grants to universities on a general waiver by the state from both copyright and patent law suits. ${ }^{204}$ Professor Meltzer has suggested that Congress condition receipt of student financial aid or research funds on the university waiving sovereign immunity with regard to claims of age and disability discrimination, as well as copyright infringemont suits. ${ }^{205}$

However, at some point the Court must enforce some sort of germaneness requirement, or the spending power will overrun any boundaries, and will allow Congress to "effectively regulate almost any area of a State's social, political, or economic life on the theory that use of the interstate transportation system is somehow enhanced."206 Justice O'Connor, in dissent in Dole, suggested the majority misapplied the germaneness test, and, in language reminiscent of the Court's strict scrutiny test in its equal protection jurisprudence, described the drinking age condition as "far too over and under-inclusive."207 She contends that the appropriate test would only allow Congress to "condition grants in ways that can fairly be said to be related to the expenditure of federal funds." ${ }^{208}$ Under this test, Congress may impose conditions related to how the states spend the federal funds. Alternatively, the condition would also be valid if Congress possessed independent power to regulate directly in that area. ${ }^{209}$ Taken together, this two-pronged germaneness test would invalidate attempts to extort adherence to unrelated regulations that Congress lacks the power to pass independently.

An agreement by state universities to accept federal adjudication under the patent law in exchange for accepting federal research grants meets even Justice O'Connor's germaneness test. Congress is entitled to

204. Scott P. Glauberman, Citizen Suits Against States: The Exclusive Jurisdiction Dilemma, 45 J. COPYRIGHT Soc'y U.S.A. 63, 108-09 (1997).

205. Meltzer, supra note 30 , at 51 .

206. Dole, 483 U.S. at 215 (O'Connor, J., dissenting).

207. Id. at 214 .

208. Id. at 217.

209. Id. 
require state universities to spend the government's research dollars in accordance with federal patent law, and the easiest way to ensure compliance is to require consent to adjudication of patent disputes in federal court. However, under Justice O'Connor's view an attempt to tie a statewide waiver of sovereign immunity to receipt of research funds would probably be too over-inclusive, because it would require waiver by all state agencies regardless of whether they receive research funding.

Congress also must ensure that the conditions on a grant are not barred by any independent constitutional provision. ${ }^{210}$ The Dole Court interpreted this third limitation on the spending power to be an "unexceptionable proposition that the power may not be used to mduce the States to engage in activities that would themselves be unconstitutional. ${ }^{.211}$ For example, Congress could not condition a grant on the state agreeing to invidiously discriminate agamst certam citizens in violation of the Fourteenth Amendinent. ${ }^{212}$ Under this interpretation, a condition that the states waive sovereign immunity would be beyond Congress's reach only if it induced the states to violate some other constitutional provision. The state commits no crime by waiving its Eleventh Amendınent immunity; indeed it is at liberty to waive sovereign immunity at any time. ${ }^{213}$ Because the condition does not require illegal activity, but rather compels adherence to federal law, it would likely overcome this limitation on the spending power.

However, the Dole Court intimated, ${ }^{214}$ and commentators have proposed, ${ }^{215}$ that the doctrine of unconstitutional conditions may define the outer limit of acceptable restrictions on federal grants. ${ }^{216}$ This doctrine asks "whether the power of government... to deny a privilege includes the power to grant it on any terms, including the surrender of an otherwise applicable constitutional right."217 The worry in the Spending Clause context is that the tremendous financial inducement of a federal grant may undermine the values of federalism by coercing the states into surrendering their constitutional rights. As the Dole Court phrased it, "in some

\footnotetext{
210. Id. at 208.

211. Id. at 210 .

212. See id.

213. See supra text accompanying notes 112-116 (describing Eleventh Amendment immunity as subject to waiver by the state at any time).

214. See Dole, 483 U.S. at 211.

215. See generally Rosenthal, supra note 187, at 1110 (suggesting that unconstitutional intrusions into state autonomy and infringment of civil liberties should limit the conditional spending power).

216. The doctrine of unconstitutional conditions affects far more than exercises of the Spending Clause. For an overview and analysis of the doctrine, see generally Kathleen M. Sullivan, Unconstitutional Conditions, 102 HARV. L. REV. 1413 (1989). For an analysis of unconstitutional conditions within the parameters of the Spending Clause, see generally Rosenthal, supra note 187.

217. Rosenthal, supra note 187 , at 1120.
} 
circumstances the financial inducement offered by Congress might be so coercive as to pass the point at which "pressure turns into compulsion."'218

Proposing that state universities waive sovereign immunity to receive research grants may trigger the doctrine of unconstitutional conditions because such a proposal conditions receipt of a valuable government benefit on a waiver of the state's constitutional right to be immune from suit in federal court. Waiver of Eleventh Amendment rights might be particularly problematic from a federalism perspective, since one of the purposes of the Amendment is to protect the states" "special and specific position in our constitutional system...."219 In Dole, however, the Court rejected. a similar argument that Congress's conditional grant coerced the state into waiving its right under the Twenty-first and Tenth Amendments to regulate in-state liquor sales. ${ }^{220}$ The Court concentrated its analysis on whether Congress actually coerced the states into accepting its condition. The Court held that the "relatively small percentage of certain federal highway funds" at risk should the state refuse to adjust its minimum drinking age could not be significant enough to constitute coercion. ${ }^{221}$

It is unclear at what point a grant becomes sufficiently necessary to the state that a condition on its receipt becomes coercive. However, federal research dollars do provide a large amount of state universities' budgets, ${ }^{222}$ and it is difficult to imagine that the current level of research at those institutions could be sustained without federal funding. Thus, a state may feel compelled to waive its immunity, or risk significant harm to its university system. The risk of the Court invalidating a conditional spending grant on these grounds seems remote, however, given Dole's broad reading of Congress's power in this area. If necessary, a less stringent-and thus less coercive-condition could be imposed by threatening to withhold only a percentage, rather than all, of federal research money from states that refuse to waive sovereign immunity.

Under the logic of Dole, a state's constitutional right to be free from suit in federal court probably does not prevent using the spending power to condition a state's waiver of sovereign immunity. However, Seminole Tribe and College Savings Bank make it clear that Congress cannot use its Article I powers to directly force the states to waive sovereign immunity. ${ }^{223}$

218. Dole, 483 U.S. at 211 (quoting Steward Machine Co. v. Davis, 301 U.S. 548, 590 (1937)).

219. Atascadero State Hosp. v. Scanlon, 473 U.S. 234, 242 (1985) (quoting Garcia v. San Antonio Metro. Transit Auth., 469 U.S. 528, 547 (1985)).

220. See Dole, 483 U.S. at 211.

221. Id.

222. Glauberman, supra note 204, at 108 \& n.9. For example, in 1999 the University of California, Berkeley received over 295 million dollars in federal research funding, out of a total of 432 million dollars. University of California, Berkelcy Awards by Sponsoring Agency, Fiscal Years 1995-99, at http://www.spo.berkeley.edu/Pages/Awards/99summary.html.

223. Supra text accompanying notes 138-146 (describing Seminole Tribe and College Savings Bank as forbidding use of Article 1 to abrogate or force a waiver of Eleventh Amendment rights). 
On its face, this would seem to bar application of the Spending Clause, an Article I power, to extract a waiver of Eleventh Amendment rights.

But the holdings in Seminole Tribe and College Savings Bank applied to direct attempts by Congress to legislate an abrogation or waiver of the Eleventh Amendinent. Use of the spending power would, in contrast, be only an indirect attempt to encourage the states to waive immunity. The states would be free to retain their immunity by choosing to forgo receipt of federal research funds. College Savings Bank's rejection of the Parden doctrine rested on an acknowledgement that Congress lacks the power under Article I to directly subject the states to suit in federal court. ${ }^{224}$ But exercises of the spending power do not depend on Congress possessing the ability to impose its desired regulation directly. ${ }^{225}$ Therefore, the limitations on Article I power described in Seminole Tribe and College Savings Bank should not limit Congress's ability to condition waiver on receipt of federal research grants under the spending power.

\section{CONCLUSION}

Florida Prepaid II and College Savings Bank have materially altered the landscape for businesses that compete with or wisli to license technology from state research universities. Under the Court's current imterpretation, the Eleventh Amendinent allows the university to dictate when and in what court its patents may be challenged. Moreover, if a state university researcher infringes patents on the way to developing a non-infringing product, the patentee has no effective method for protecting her federal intellectual property rights. The Court's decisions come at a time whien state universities are rapidly expanding their acquisition and enforcement of intellectual property rights. Iromically, federal researcli grants help fund much of the researcli that leads to the inventions the universities are seeking to patent.

Many responses to this problem focus on conditioning receipt of a patent right on waiver of sovereign immunity from suits under the patent law. This approach may lead to several difficulties. First, should the state decide to forgo patents and not waive sovereign immunity, the federally funded research at its state universities will go unprotected. This result would undermine the mcentive structure at the heart of the Bayli-Dohl approacli to patenting federally funded inventions, and might result in a net loss to the public of useful inventions that industry will not develop without an exclusive license. Furthermore, this solution does not address the problem of patentees aggrieved by states that choose not to waive their sovereign immunity by applying for a patent. Finally, solutions based on conditioning a waiver on receipt of a patent may not survive the rule in

224. College Savings Bank, 527 U.S. 666, 697 (1999) (Breyer, J., dissenting).

225. See Dole, 483 U.S. at 207. 
College Savings Bank, which denies Congress the power under Article I to force a state to waive immunity.

Conditioning federal research grants on waiver of Eleventh Amendment immunity from suits arising from research activity closes the Florida Prepaid II loophole without risking the mcentive structure of the Bayh-Dohl Act. If a state chooses to forgo federal research funds, its university simply will be far less able to engage in the sorts of activities that give rise to patentable inventions. Universities that do choose to participate in federally funded research programs will be able to receive patents on their inventions, subject to the same regulations and restrictions as private parties. 